(c) American Dairy Science Association, 2002.

\title{
Adenoviral-Mediated Transfer of a Lysostaphin Gene into the Goat Mammary Gland
}

\author{
W. Fan, K. Plaut, A. J. Bramley, \\ J. W. Barlow, and D. E. Kerr \\ Department of Animal Science \\ College of Agricultural \& Life Sciences \\ University of Vermont, Burlington 05405
}

\begin{abstract}
As a step toward preventing and curing Staphylococcus aureus mastitis, an adenoviral-mediated gene transfer technique was used to enable mammary cells to synthesize and secrete lysostaphin, an anti-staphylococcal protein. A lysostaphin gene, modified for eukaryotic expression of the bioactive variant, $\mathrm{Gln}^{125,}{ }^{232}$-lysostaphin, was inserted into a replication deficient adenovirus by homologous recombination in 293 cells. The resulting adenoviral vector containing the modified lysostaphin gene (Ad-lys) was used to infect bovine mammary epithelial cells in vitro and caprine mammary cells in vivo. A similar adenoviral vector containing the Escherichia coli gene encoding $\beta$-galactosidase (Ad$l a c Z$ ) was also evaluated. Transduction of cultured bovine cells by Ad-lac $Z$ was confirmed by the presence of $\beta$-galactosidase in fixed cells $48 \mathrm{~h}$ postinfection. Bovine cells transduced by Ad-lys secreted immunoreactive $\mathrm{Gln}^{125,232}$-lysostaphin $(0.8 \mu \mathrm{g} / \mathrm{ml})$ into media that had approximately $20 \%$ bioactivity compared with native lysostaphin. To evaluate transduction in vivo, udder halves of four nonlactating goats were exposed to $10^{10}$ plaque-forming units (pfu) of Ad-lac $Z$ by two intramammary infusions given $48 \mathrm{~h}$ apart. The animals were euthanized $24 \mathrm{~h}$ later, and extensive expression of $\beta$ galactosidase was detected in cells lining the teat canals, with more moderate expression observed in adjoining mammary parenchyma. Udder halves of two other nonlactating goats were infused with $10^{10} \mathrm{pfu}$ of Ad-lys while contralateral udder halves received Adlac $Z$. The animals were euthanized $48 \mathrm{~h}$ postinfusion. In both animals, extensive expression of $\beta$-galactosidase was detected in Ad-lac $Z$ exposed teats. Immunoreative $\mathrm{Gln}{ }^{125,232}$-lysostaphin was detectable in secretions from Ad-lys exposed glands $24 \mathrm{~h}$ postinfusion, increasing to approximately $1 \mu \mathrm{g} / \mathrm{ml}$ at $48 \mathrm{~h}$ postinfusion. As with cultured bovine mammary epithelial cells, the bio-
\end{abstract}

Received January 8, 2002.

Accepted February 18, 2002.

Corresponding author: D. E. Kerr; e-mail: dkerr@zoo.uvm.edu. activity of goat-derived $\mathrm{Gln}^{125,}{ }^{232}$-lysostaphin was approximately $20 \%$ of native lysostaphin. These results demonstrate that an adenoviral vector can be used to introduce a gene into the ruminant mammary gland, enabling the secretion of a bioactive form of lysostaphin. (Key words: mastitis, adenovirus, lysostaphin, gene therapy)

Abbreviation key: Ad-lac $Z$ = recombinant adenoviral vector containing the Escherichia coli lac Z gene, Ad-lys $=$ recombinant adenoviral vector containing a modified lysostaphin gene, BME-UV = bovine mammary epithelial cell line-University of Vermont, hGH = human growth hormone, $\boldsymbol{l a c} \boldsymbol{Z}=E$. coli gene encoding $\beta$-galactosidase, $\mathbf{X}$-gal $=5$-bromo-4-chloro-3-indolyl- $\beta$-D-galactoside.

\section{INTRODUCTION}

Mastitis is an inflammation of the mammary gland, usually caused by microbial infection. The classic symptoms of mastitis include inflammation and swelling of the mammary glands and elevated SCC in milk. It decreases milk production and milk quality and increases herd management cost. Current practices to combat mastitis are based on a five-point control plan (Bramley and Dodd, 1984) that recommends use of correctly maintained milking equipment, postmilking teat sanitation, both therapeutic and prophylactic use of antibiotics, and culling of persistently infected animals. Systematic application of antibiotic therapy at dry-off cures a number of infections and plays a role in prevention of new infection during this susceptible period. However, reliance on antibiotics that are also used to combat human disease has raised concerns over the development of resistant bacterial strains. We are attempting to develop new strategies to prevent mastitis by enabling the cells of the mammary gland to produce novel antibacterial proteins.

Lysostaphin, a 27-kDa protein produced by Staphylococcus simulans, has potent staphylolytic activity (Schindler and Schuhardt, 1964). It causes lysis of staphylococci, including a major mastitis-causing 
pathogen, Staphylococcus aureus, by cleaving pentaglycine linkages in the peptidoglycan of the bacterial cell wall (Schindler and Schuhardt, 1965). It has been demonstrated that treatment with lysostaphin significantly reduced viable $S$. aureus in a mouse model of $S$. aureus mastitis (Bramley and Foster, 1990) and a bovine mastitis model (Oldham and Daley, 1991). We have recently modified the bacterial lysostaphin gene to enable eukaryotic secretion of a bioactive variant of lysostaphin (Gln ${ }^{125,232}$-lysostaphin). Transgenic mice secreting this protein into milk under the control of the $5^{\prime}$ flanking region of the ovine $\beta$-lactoglobulin gene exhibit substantial resistance to mastitis from intramammary challenge with S. aureus (Kerr et al., 2001). This transgenic animal approach has great potential, but clearly there will be considerable delay between the development of founder animals and dissemination of the new genetic material into production herds (Wall et al., 1997).

A more rapid alternative to transgenesis would be the direct delivery of genes encoding antimicrobial proteins into the mammary gland. This approach draws on the wealth of data generated by those pursuing human gene therapy. Both viral and nonviral vectors have been used to deliver genes to a variety of sites in a variety of animal species and in humans. Mammary glands, in vivo, have been transduced with a retroviral strategy (Archer et al., 1994) and transfected by plasmid DNA (Kerr et al., 1996; Hens et al., 2000) designed to cause secretion of a reporter gene, human growth hormone into milk. In these experiments, the reporter gene product was detected in milk at 20 to $60 \mathrm{ng} / \mathrm{ml}$ (Archer et al., 1994), less than $5 \mathrm{ng} / \mathrm{ml}$ (Kerr et al., 1996), and up to $500 \mathrm{ng} / \mathrm{ml}$ (Hens et al., 2000). It is unknown whether similar relatively low concentrations of a potent therapeutic protein would be effective for mastitis control. A major drawback of the retroviral approach is the need for cells to divide for transfection to succeed, while the plasmid DNA approach seems to suffer from low transfection efficiency. Rodent mammary glands have also been transduced in vivo with recombinant adenoviral vectors designed to express the $\beta$-galactosidase (lacZ) reporter gene (Yang et al., 1995; Jeng et al., 1998). The current study was designed to determine the effectiveness of adenoviral-mediated transduction of ruminant mammary cells and whether that strategy would enable those cells to secrete lysostaphin.

\section{MATERIALS AND METHODS}

\section{Construction of an Adenoviral Vector Containing a Lysostaphin Gene (Ad-lys)}

The modified lysostaphin gene linked to an upstream human growth hormone ( $\boldsymbol{h} \boldsymbol{G H})$ secretion signal se- quence was excised from the plasmid (pSec-Gln ${ }^{125,}{ }^{232}$ Lys) previously described (Kerr et al., 2001). The gene encodes a lysostaphin variant ( $\mathrm{Gln}^{125,232}$-Lys) that is secreted in a bioactive form by eukaryotic cells. The two amino acid substitutions in the variant form were generated to remove eukaryotic glycosylation sites from the native bacterial form of the protein. The DNA fragment was then inserted into a shuttle plasmid, pAvS6A (Smith et al., 1993), obtained from B. C. Trapnell (Genetic Therapy Inc., Gaithersburg, MD) to generate the shuttle plasmid pAvS6Alys $\Delta$ G1n2. A replication deficient adenovirus ( $A d d l$ 327) obtained from Trapnell was propagated in the 293 packaging cell line (CRL 1753, American Type Culture Collection, Manassas, VA). Adenovirus was extracted and purified by density gradient ultracentrifugation as described (Rosenfeld et al., 1992; Mittereder et al., 1994). The adenovirus preparation was then adjusted to $10 \%$ glycerol and dialyzed against $4 \mathrm{~L}$ of dialysis buffer (10 $\mathrm{m} M$ Tris $\mathrm{pH} 7.4,1 \mathrm{~m} M \mathrm{MgCl}_{2}$, $10 \%$ glycerol). Adenovirus particles were digested by diluting the stock solution with an equal volume of a buffer solution (10 $\mathrm{m} M$ Tris-HCl, $1 \mathrm{~m} M$ EDTA, $\mathrm{pH}$ 7.4) containing proteinase $\mathrm{K}(1 \mathrm{mg} / \mathrm{ml})$ and SDS (1\%). Adenoviral DNA was then extracted, digested with ClaI, and separated by low-voltage electrophoresis on a $1 \%$ agarose gel for $14 \mathrm{~h}$ in darkness to avoid shearing and UV damage. The 35-kb ClaI DNA fragment was extracted from the agarose gel by electroelution. Recombinant adenovirus was then produced through homologous recombination by cotransfection of 293 cells with the adenoviral Cla 1 fragment and linearized $(K p n I)$ pAvS6Alys $\Delta$ G1n2 shuttle plasmid. Twelve hours after cotransfection, the media was removed, the plates were washed three times with PBS, and then were overlaid with media containing $1 \%$ seaplaque agarose (FMC BioProducts, Rockland, MD). Recombinant adenoviral vectors produced individual clear zones that were carefully picked off the plate and transferred to new tubes. The vectors were further subcloned to ensure clonality. Presence of the modified lysostaphin gene in the recombinant adenoviral vector (Ad-lys) was verified by PCR. Staphylolytic activity in the cell culture media, indicative of lysostaphin activity, was determined as described below. Large-scale preparations of adenoviral vector were prepared and titred by plaque assay on confluent 293 cells. The titer of the final Ad-lys stock preparation was $2 \times 10^{10} \mathrm{pfu} / \mathrm{ml}$. The preparation was stored at $-80^{\circ} \mathrm{C}$.

\section{Transduction of Bovine Mammary Epithelial Cells in Vitro}

A recombinant adenoviral vector containing the Escherichia coli lac $Z$ gene led by a nuclear targeting 
sequence (Ad-lacZ) was obtained from B. C. Trapnell. It was constructed in a fashion similar to Ad-lys, and both vectors contain the same adenoviral backbone. Large-scale preparation and titering of Ad-lacZ was performed as described previously for Ad-lys.

A bovine mammary epithelial cell line developed at the University of Vermont (BME-UV) was obtained from B. Zavizion (University of Vermont, VT) and cultured accordingly (Zavizion et al., 1996) in complete media containing $10 \%$ fetal bovine serum. The BMEUV cells were grown to confluency in cell culture dishes and then exposed for $1.5 \mathrm{~h}$ to Ad-lacZ or Ad-lys at approximately $50 \mathrm{pfu} / \mathrm{cell}$ in complete media containing $2 \%$ fetal bovine serum. Transduction media was then replaced with fresh complete media. Media from individual wells was collected $8,22,30$, and $44 \mathrm{~h}$ posttransduction. For comparison purposes, 293 cells were transduced by the same protocol with media collected $24 \mathrm{~h}$ posttransfection.

\section{Transduction of Goat Mammary Gland Cells in Vivo}

Nonlactating, multiparous, Toggenburg goats were housed individually in metabolism crates to allow for total collection of urine and feces that were subsequently autoclaved before disposal or incinerated. During the trial, for all infusions and sample collections, teats were routinely prewiped with alcohol and postdipped with iodine to prevent mammary gland infection.

In the first experiment, right mammary glands of four goats were infused with $1 \mathrm{ml}$ containing $1.9 \times 10^{10}$ $\mathrm{pfu} / \mathrm{ml} \mathrm{Ad-lacZ}$ on d 0 , and $1 \mathrm{ml}$ containing $0.6 \times 10^{10}$ $\mathrm{pfu} / \mathrm{ml}$ Ad-lac $Z 48 \mathrm{~h}$ later. Left glands served as controls and received the same volumes of infusion diluent (10 $\mathrm{m} M$ Tris $\mathrm{pH} 7.4,1 \mathrm{mM} \mathrm{MgCl}_{2}, 10 \%$ glycerol). Mammary secretions were collected immediately before and $24 \mathrm{~h}$ after each infusion. The SCC of mammary secretions was determined with a Fossomatic 90 following manufacturer's instructions (Foss Electric, Hillerod, Denmark). Twenty-four hours after the second infusion, the goats were euthanized. Teats and mammary tissues were collected and processed as described below to detect lac $Z$ expression.

In the second experiment, left mammary glands of two goats were infused with $1 \mathrm{ml}$ containing $1.5 \times 10^{10}$ $\mathrm{pfu} / \mathrm{ml}$ Ad-lac $Z$, while right glands received $1 \mathrm{ml}$ containing $1.5 \times 10^{10} \mathrm{pfu} / \mathrm{ml}$ Ad-lys. Forty-eight hours later the goats were euthanized. Mammary secretions were collected 24 and $48 \mathrm{~h}$ postinfusion. Teats and mammary tissues were collected at euthanasia.

\section{Detection of lacZ Expression}

Immediately after the final collection of media, cell culture plates were washed three times with PBS and fixed for $30 \mathrm{~min}$ at $37^{\circ} \mathrm{C}$ with $0.5 \mathrm{ml} /$ well of $1.25 \%$ glutaraldehyde in PBS. The cells were then washed and incubated with $1 \mathrm{ml}$ of $0.1 \%$ BSA in PBS for $20 \mathrm{~min}$ at room temperature. The cells were washed again and incubated for $30 \mathrm{~min}$ at $37^{\circ} \mathrm{C}$ with $0.5 \mathrm{ml} /$ well of 5 bromo-4-chloro-3-indolyl- $\beta$-D-galactoside (X-gal) reaction buffer (0.1 $M$ sodium phosphate buffer, $\mathrm{pH} 7.3,2$ $\mathrm{mM} \mathrm{MgCl} 2$ and $5 \mathrm{mM}$ potassium ferricyanide, $5 \mathrm{~m} M$ potassium ferrocyanide, $0.02 \% \mathrm{NP}-40$ and $0.01 \%$ sodium deoxycholate). The buffer was then replaced with an X-gal-containing buffer $(1 \mathrm{mg} / \mathrm{ml})$ prepared from an $\mathrm{X}$-gal stock solution $(50 \mathrm{mg} / \mathrm{ml}$ in dimethyl sulfoxide) that was freshly diluted in reaction buffer (Sanes et al., 1986).

Teat and mammary tissue samples were immediately placed into vials containing $10 \mathrm{ml}$ of cold $\left(4^{\circ} \mathrm{C}\right) 2 \%$ paraformaldehyde, $0.02 \%$ glutaraldehyde in PBS. Two hours later, the tissues were rinsed three times with $\mathrm{PBS}$, and incubated for $2 \mathrm{~h}$ at $30^{\circ} \mathrm{C}$ in $\mathrm{X}$-gal reaction buffer. The buffer was then replaced with X-gal-containing buffer and the tissues were incubated for 24 to $48 \mathrm{~h}$ at $30^{\circ} \mathrm{C}$. The tissues were then washed with PBS to avoid nonspecific color development.

\section{Detection of Lysostaphin}

Immunoreactive lysostaphin in cell culture media and samples was detected by ELISA and Western blot analysis using an affinity purified rabbit anti-lysostaphin antibody as the primary antibody (Kerr et al., 2001). Recombinant lysostaphin (Sigma Chemical Co., St. Louis, MO) served as standard. Staphylolytic activity was detected by exposure of freshly streaked $S$. aureus (strain M60) to $15-\mu$ l aliquots of standards or samples that were previously concentrated sixfold by lyophilization and reconstitution in $\mathrm{H}_{2} \mathrm{O}$. In samples containing detectable amounts of bioactive lysostaphin, lytic zones were visible in the lawn of bacteria that developed after overnight incubation at $37^{\circ} \mathrm{C}$.

\section{RESULTS}

\section{Transduction of Bovine Mammary Epithelial Cells in Vitro}

Successful transduction of BME-UV cells by a human adenoviral vector was observed as intense nuclear staining with X-gal reagent in approximately $80 \%$ of cells that had been exposed to Ad-lacZ. Similar staining was observed in transduced 293 cells (data not presented). 


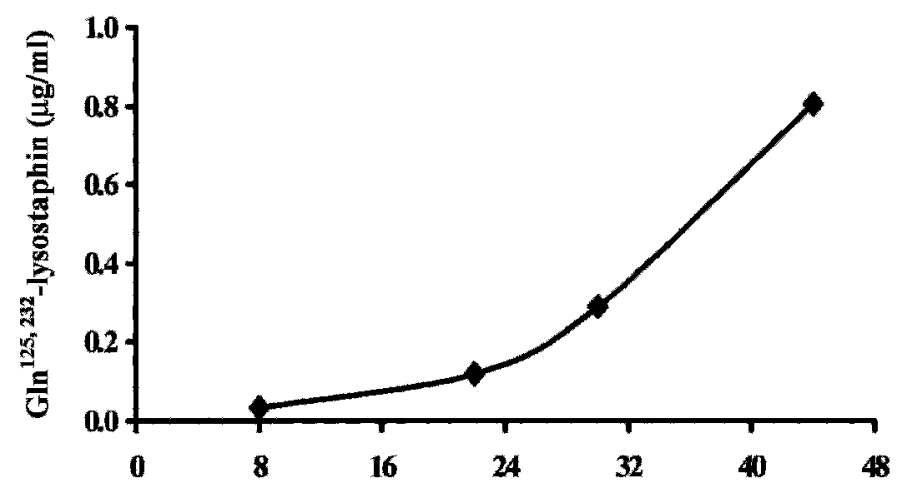

Hours Post-Transduction

Figure 1. Secretion of $\mathrm{Gln}^{125,232}$-lysostaphin into culture media by bovine mammary epithelial cells transduced with an adenoviral vector containing a modified lysostaphin gene.

Transduction of BME-UV cells with Ad-lys resulted in the secretion of immunoreactive Gln ${ }^{125},{ }^{232}$-lysostaphin into cell culture media. This protein was detectable $8 \mathrm{~h}$ post-exposure to the adenovirus and media concentrations continued to increase throughout the 44-h incubation period, reaching $0.8 \mu \mathrm{g} / \mathrm{ml}$ (Figure 1). Lysostaphin immunoreactivity was undetectable in cell lysates. The ability of the mammary cell-derived $\mathrm{Gln}^{125}$, ${ }^{232}$-lysostaphin to kill $S$. aureus was confirmed by a bacterial plate assay. Bioactivity was present in the cell culture media of Ad-lys transduced BME-UV or 293 cells (Figure 2). Activity was not detected in media of cells transduced with Ad-lacZ, nor was activity detected in any cell extracts. An approximation of the relative bioactivity of LYS produced by BME-UV cells with that of recombinant lysostaphin was made by comparing media immunoreactive concentrations, determined by ELISA, with staphylolytic activity determined by bacterial growth inhibition. A representative media sample containing $0.8 \mu \mathrm{g} / \mathrm{ml}$ of immunoreactive LYS was concentrated sixfold and found to exhibit staphylolytic activity similar to a $1 \mu \mathrm{g} / \mathrm{ml}$ standard solution of recombinantly produced prokaryotic lysostaphin, although less than a standard containing $2 \mu \mathrm{g} / \mathrm{ml}$ (Figure 2). This suggests that the Gln ${ }^{125,}{ }^{232}$-lysostaphin variant, produced eukaryotically, has approximately $20 \%$ of the bioactivity of the recombinantly produced prokaryotic form. Western blot analysis of media samples confirmed the secretion of $\mathrm{Gln}^{125}$, ${ }^{232}$-lysostaphin and indicated that the protein was of similar molecular weight (27 $\mathrm{kDa}$ ) to that of recombinant lysostaphin (Figure 3).

\section{Transduction of Goat Mammary Glands in Vivo}

The goats all appeared bright, alert, and reactive throughout the treatment period, and all goats were

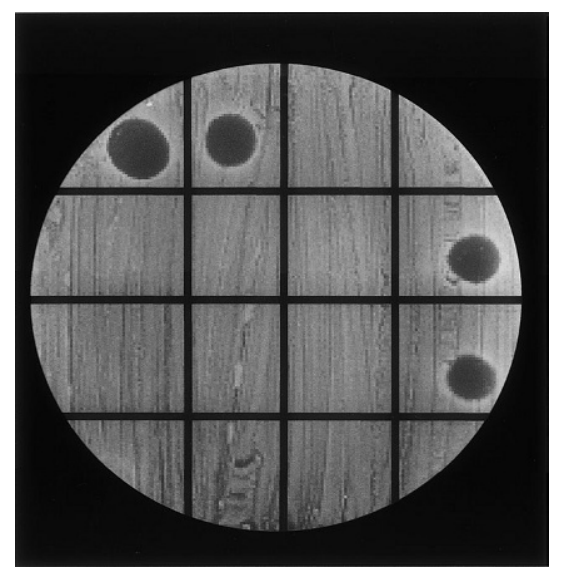

Figure 2. Anti-staphylolytic activity detected by growth inhibition zones that appear $16 \mathrm{~h}$ after exposure of a freshly streaked lawn of Staphylococcus aureus to standards ( $15 \mu \mathrm{l} / \mathrm{drop})$ or sixfold concentrated samples ( $15 \mu \mathrm{l} / \mathrm{drop})$. Top row, from left to right: Recombinant, bacterially derived lysostaphin at concentrations of 2.0, 1.0, 0.5, 0.25 $\mu \mathrm{g} / \mathrm{ml}$; Second row, from left to right: cell extract and cell culture media of 293 cells infected with a recombinant adenoviral vector containing the Escherichia coli lacZ gene (Ad-lacZ), and cell extract and cell culture media of 293 cells infected with a recombinant adenoviral vector containing a modified lysostaphin gene (Ad-lys), respectively. Third row, from left to right: Cell extract and cell culture media of bovine mammary epithelial (BME-UV) cells infected with Ad-lacZ, and cell extract and cell culture media of BME-UV cells infected with Ad-lys, respectively. Bottom row, conditioned cell extract and cell culture media of BME-UV cells, and conditioned cell extract and cell culture media of 293 cells.

\section{$\begin{array}{llllllll}1 & 2 & 3 & 4 & 5 & 6 & 7 & 8\end{array}$}

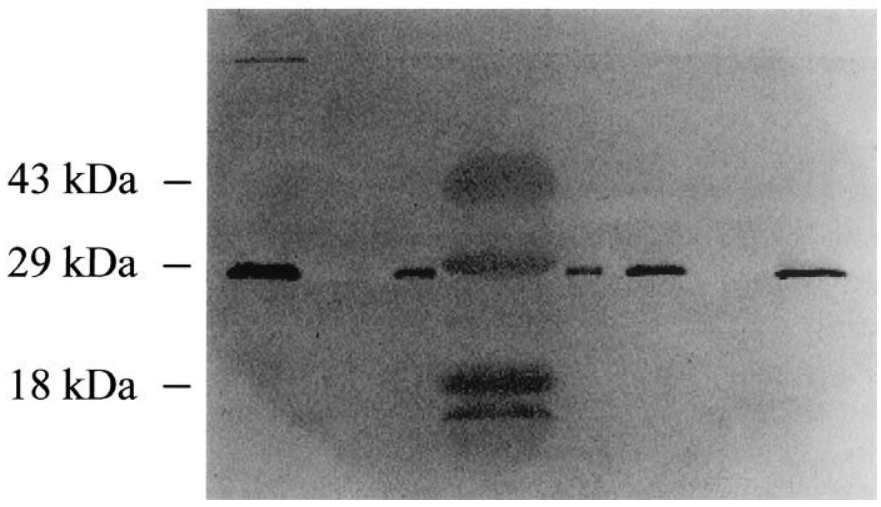

Figure 3. Western blot analysis of lysostaphin secreted into media by cells transduced with a recombinant adenoviral vector containing a modified lysostaphin gene (Ad-lys). Lanes 1 and 3: Culture media (5 and $1 \mu \mathrm{l}$, respectively) from transduced 293 cells. Lane 2 : Nontransduced 293 cell conditioned media $(5 \mu \mathrm{l})$. Lane 4: Protein molecular weight marker. Lanes 5 and 6: Culture media (2.5 and $10 \mu$ l, respectively) from transduced bovine mammary epithelial (BME-UV) cells. Lane 7: Nontransduced BME-UV cell conditioned media $(10 \mu \mathrm{l})$. Lane 8: $10 \mu \mathrm{l}$ of $1 \mu \mathrm{g} / \mathrm{ml}$ bacterial lysostaphin in BME-UV cell conditioned media. 


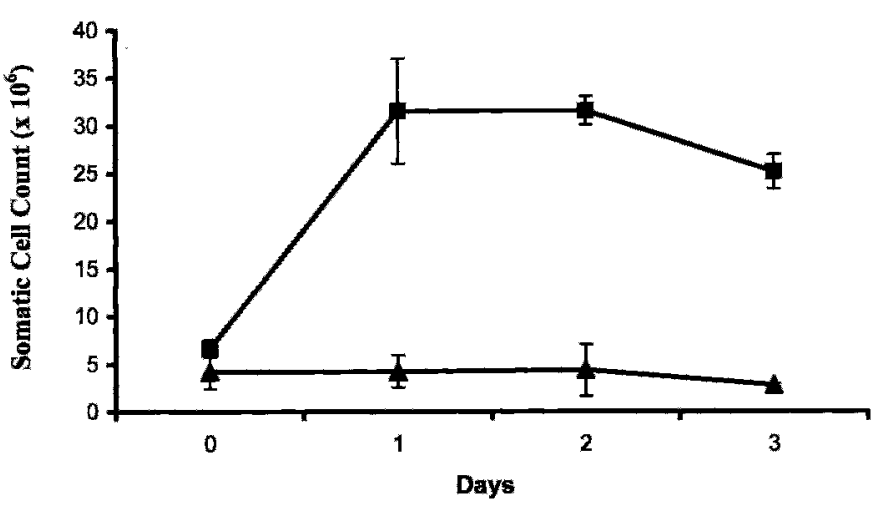

Figure 4. Somatic cell count of mammary secretions obtained from goats infused with a recombinant adenoviral vector containing the

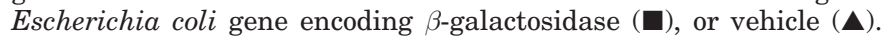
Infusions were given after sample collection on $\mathrm{d} 0$ and 2 (mean $\pm \mathrm{S}$. E.; $n=4)$.

considered in normal health. Mild swelling of the glands and markedly increased SCC in mammary secretions was noted in all glands infused with adenoviral vectors (Figure 4).

In Ad-lac Z treated udders, bright blue staining-indicative of $\beta$-galactosidase expression-was observed throughout the teat cistern and to a lesser extent in mammary parenchyma adjacent to the teat (Figure 5A). No staining was observed in Ad-lys or vehicle treated glands. Histological examination revealed that the X-

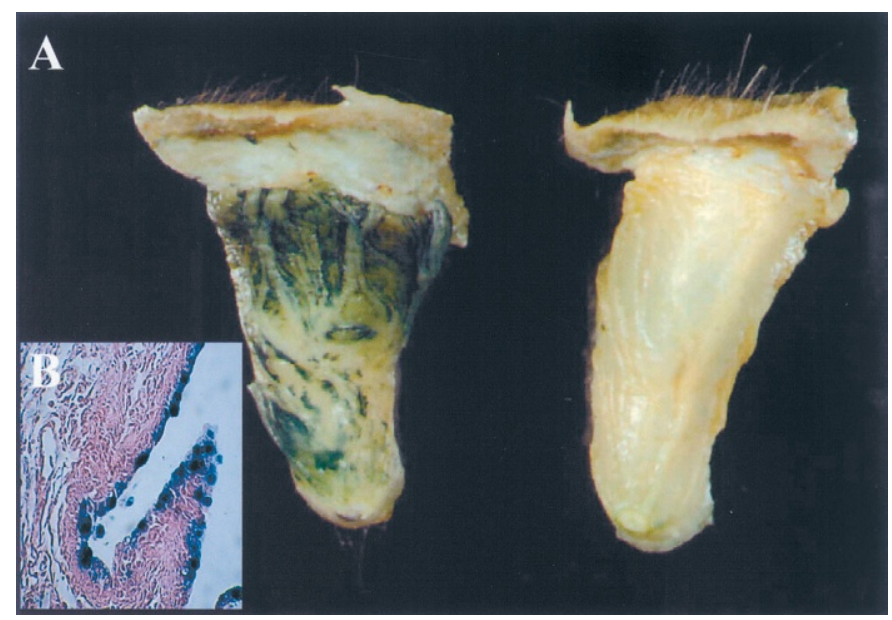

Figure 5. (A) Everted mammary teats obtained from a representative goat following intramammary infusion of a recombinant adenoviral vector containing the Escherichia coli gene encoding $\beta$-galactosidase (left teat) or vehicle (right teat). The teats were subsequently exposed to a solution containing 5 -bromo-4-chloro-3-indolyl- $\beta$-D-galactoside that produces a blue precipitate in the presence of $\beta$-galactosidase. The blue coloration indicates that the vector-delivered gene is being expressed in the tissue. (B) Microscopic view (400X) of the luminal surface of the left teat. The paraffin section was counterstained with eosin. gal stain was localized to nuclei of the single epithelial layer lining the teat cistern (Figure 5B).

Lysostaphin concentrations of $0.2 \mu \mathrm{g} / \mathrm{ml}$ and $0.6 \mu \mathrm{g} /$ $\mathrm{ml}$ on $\mathrm{d} 1$ and of $0.9 \mu \mathrm{g} / \mathrm{ml}$ and $1.1 \mu \mathrm{g} / \mathrm{ml}$ on $\mathrm{d} 2$ were detected in the secretions of right glands of the two goats infused with Ad-lys. No lysostaphin expression was detected in the secretions of Ad-lacZ treated udders. Mammary gland produced lysostaphin was approximately $27 \mathrm{kDa}$ as revealed by Western blot analysis (Figure 6). However, only faint staphylolytic activity could be detected in the secretions (data not presented), probably because of the low lysostaphin concentration present.

\section{DISCUSSION}

Mastitis due to $S$. aureus often results in a chronic condition wherein the animal's innate defense mechanisms are unable to fully clear the infection. The resulting subclinical infection then serves as a reservoir for the pathogen that can spread to herdmates and flare up into clinical cases. Antibiotic therapy of lactating animals is expensive due to the mandatory discard of milk from treated animals and is often ineffective. Culling of infected animals or drying off and application of antibiotic-containing dry-cow formulations are more effective remedies. Our goal is to enable the cells of the mammary gland to produce novel antibacterial proteins such as lysostaphin. In the present study we have demonstrated that a recombinant human adenovirus can transduce ruminant mammary epithelial cells enabling them to secrete $\operatorname{Gln}^{125,}{ }^{232}$-lysostaphin, and as a first step toward production of a dry-cow therapeutic, we

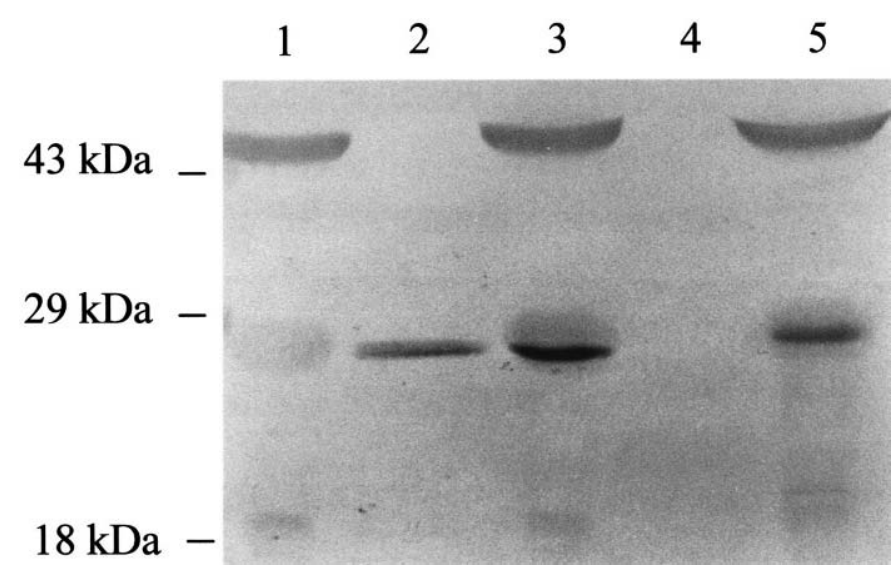

Figure 6. Western blot analysis of lysostaphin in goat mammary secretions. Lane 1: Preinfusion secretion, Lane 2: $1 \mu \mathrm{g} / \mathrm{ml}$ of bacterial lysostaphin in PBS, Lane 3: $1 \mu \mathrm{g} / \mathrm{ml}$ bacterial lysostaphin in preinfusion secretion, Lane 4: blank, Lane 5: goat secretion from a gland that had been infused with a recombinant adenoviral vector containing a modified lysostaphin gene. 
have shown transduction of nonlactating glands of multiparous goats in vivo. The concentration of $\mathrm{Gln}^{125,}{ }^{232}$ lysostaphin detected in the goat mammary secretions climbed to approximately $1 \mu \mathrm{g} / \mathrm{ml} 48 \mathrm{~h}$ postinfusion. Whether this concentration of $\mathrm{Gln}^{125}{ }^{232}$-lysostaphin would be effective in preventing mastitis is unknown; however, this protein is being produced in the region of the teat orifice where a relatively low concentration of staphylolytic activity would form an effective barrier to penetration by $S$. aureus. Given that mastitis causing pathogens enter the gland through the streak canal, extensive transduction of cells lining the teat cistern with novel antibacterial encoding genes may be ideal for the prevention of mastitis.

The potent staphylolytic activity of lysostaphin is well known. Its usefulness as a mastitis therapeutic was first demonstrated in a mouse mastitis model (Bramley and Foster, 1990). In that report, infusion of the lactating murine mammary gland with $10 \mu \mathrm{g}$ of lysostaphin, either concurrent with or $1 \mathrm{~h}$ before inoculation with $10^{8} \mathrm{cfu}$ of $S$. aureus, reduced the recovery of bacteria by more than $6 \log _{10}$ and greatly reduced the pathological changes typical of $S$. aureus mastitis. Use of a bovine mastitis model subsequently demonstrated the effectiveness of intramammary lysostaphin administration to combat mastitis in dairy cows (Oldham and Daley, 1991). Treatment of infected quarters with lysostaphin was found to be as effective as similar treatment with sodium cephapirin, while both treatments were superior to penicillin. As further support to lysostaphin's effectiveness, we recently reported that transgenic mice capable of secreting $G \ln ^{125}, 232$-lysostaphin into their milk have substantial resistance to an intramammary challenge with $10^{4} \mathrm{cfu}$ of $S$. aureus (Kerr et al., 2001). Mice from the line with greatest lysostaphin production were entirely resistant to the bacterial challenge.

The transgenic animal approach appears clearly effective; however, primarily due to the length of bovine gestation, it will take considerable time before the strategy is actually used in the national dairy herd. Regulatory hurdles not withstanding, it has been estimated that at least $7 \mathrm{yr}$ will be required between the birth of the first transgenic calf containing the desired transgene and the generation of milk from herds of transgenic production animals (Wall et al., 1997). An alternative approach is to deliver the desired gene to the mammary cells of existing individual animals. Our current work explores the effectiveness of adenoviralmediated gene transfer. Previous reports have explored retroviral- and plasmid DNA-based approaches (Archer et al., 1994; Hens et al., 2000).

Retroviral-mediated transduction requires infection of dividing cells. For this reason, Archer et al. (1994) performed their retroviral experiments during a period of hormonally induced development of the lactating goat mammary gland. The glands were infected via mammary infusion on $\mathrm{d} 3,5,7,9,11$, and 13 of the hormonal regimen with a retroviral vector encoding hGH. Lactation commenced on d 14 of the hormonal regimen. The highest hGH concentration in milk $(<100$ $\mathrm{ng} / \mathrm{ml}$ ) was observed on the first day of lactation then declined to plateau levels of approximately $10 \mathrm{ng} / \mathrm{ml}$ that were maintained from d 4 until d 15 , when milking was stopped. Hens et al. (2000) enabled expression of $\mathrm{hGH}$ in guinea pig mammary glands via intramammary infusion of plasmid DNA encoding hGH. They were able to detect hGH in milk throughout the 14-d lactation period with peak level of approximately $500 \mathrm{ng} / \mathrm{ml} \mathrm{ob-}$ served on $d 5$. The results of these two studies are encouraging, but we felt that an adenoviral approach would be superior based on reports of its high transfection efficiency and its ability to transduce nonreplicating cells.

Adenovirus has a broad host range and is efficient at gene delivery (Trapnell and Gorziglia, 1994). Adenoviral DNA generally does not integrate into the host cell chromosome and thus this strategy will result in transient expression of the potentially therapeutic gene. A number of reports indicate that expression can persist for 1 to 2 mo (Connelly et al., 1995, 1996; Chen et al., 1997a, 1997b). Immune responses to the adenovirus and the therapeutic gene products appear to limit the persistency of expression, but new generations of adenoviruses and oral tolerization strategies are being pursued to extend the persistency of expression (Ilan et al., 1997a, 1997b; Chen et al., 1997a; Ilan et al., 1997b). There is good potential that the duration of adenoviralmediated mammary expression of an antibacterial protein given at dry-off would be sufficient to offer protection during the standard 2-mo dry period. The appropriate vector could also be infused into the developing mammary gland during the latter part of an animal's first gestation to offer protection during this mastitis susceptible period.

Adenoviral-mediated transduction of the bovine mammary epithelial cell line and cells lining the goat teat cistern with the lac $Z$ gene demonstrated the effectiveness of this gene delivery approach. High efficiency transduction was observed in cells exposed to the virus. The moderate transduction of mammary parenchyma adjacent to the teat likely indicates limited penetration of the virus within the mammary gland. We selected a dose of $10^{10} \mathrm{pfu}$ of adenoviral vector to achieve a multiplicity of infection of one based on estimation that there are $10^{10}$ epithelial cells in the goat mammary gland (Archer et al., 1994). Previous reports with intramammary dye infusion techniques in lactating rats in- 
dicated extensive penetration of the infusate throughout the gland (Patton et al., 1984). However, the distribution range in nonlactating goat glands appears to have been limited, likely by the highly viscous nature of the dry gland secretion. Larger infusion volumes, such as the 20-ml volume used by Archer et al. (1994) in their infusion of retroviral vector into goat mammary glands, may lead to greater transduction of goat mammary parenchyma and a subsequent increase in $\mathrm{Gln}^{125 \text {, }}$ ${ }^{232}$-lysostaphin concentration.

We were able to transduce bovine mammary epithelial cells in vitro and caprine mammary cells in vivo with a replication deficient adenovirus containing a modified lysostaphin gene previously used to generate mastitis resistant transgenic mice (Kerr et al., 2001). The lysostaphin produced by the transduced cells was found to have approximately $20 \%$ of the bioactivity of recombinant prokaryotic form. A similar reduction in bioactivity was observed in the lysostaphin produced by transgenic mice. The reduced bioactivity of $\mathrm{Gln}^{125}$, ${ }^{232}$-lysostaphin is a characteristic of the variant form and does not reflect the method that was used to introduce the gene into cells.

\section{CONCLUSION}

This study demonstrates that a modified lysostaphin gene can be introduced into bovine epithelial cells in vitro and goat mammary cells in vivo by an adenoviral-mediated gene transfer technique. Secretion of the encoded lysostaphin variant was detected, both immunologically and biologically, in cell culture media and mammary secretions. More studies are necessary to enhance the bioactivity of the lysostaphin variant and to determine the duration of expression with a view to preventing and treating staphylococcal infection of the mammary glands.

\section{ACKNOWLEDGMENTS}

Acknowledgments are made to the Northeast Dairy Foods Research Center and Vermont Dairy Promotion Council for the financial support for this study. The authors appreciate Woody Pankey for his genuine support for this project. The authors also thank Patricia Murdough, Rhonda Maple, Jeffrey White, Fran Kinghorn, Jane O'Neil, Dr. Scott Mischler and the University of Vermont farm crew for their assistance throughout the study.

\section{REFERENCES}

Archer, J. S., W. S. Kennan, M. N. Gould, and R. D. Bremel. 1994. Human growth hormone (hGH) secretion in milk of goats after direct transfer of the hGH gene into the mammary gland by using replication- defective retrovirus vectors. Proc. Natl. Acad. Sci. USA 91:6840-6844.

Bramley, A. J., and F. H. Dodd. 1984. Reviews of the progress of dairy science: Mastitis control-progress and prospects. J. Dairy Res. 51:481-512.

Bramley, A. J., and R. Foster. 1990. Effects of lysostaphin on Staphylococcus aureus infections of the mouse mammary gland. Res. Vet. Sci. 49:120-121.

Chen, H. H., L. M. Mack, R. Kelly, M. Ontell, S. Kochanek, and P. R. Clemens. 1997a. Persistence in muscle of an adenoviral vector that lacks all viral genes. Proc. Natl. Acad. Sci. USA 94:1645-1650.

Chen, L. M., L. Chao, and J. Chao. 1997b. Adenovirus-mediated delivery of human kallistatin gene reduces blood pressure of spontaneously hypertensive rats. Hum. Gene Ther. 8:341-347.

Connelly, S., J. M. Gardner, A. McClelland, and M. Kaleko. 1996. High-level tissue-specific expression of functional human factor VIII in mice. Hum. Gene Ther. 7:183-195.

Connelly, S., T. A. G. Smith, G. Dhir, J. M. Gardner, M. G. Mehaffey, K. S. Zaret, A. McClelland, and M. Kaleko. 1995. In vivo gene delivery and expression of physiological levels of functional human factor VIII in mice. Hum. Gene Ther. 6:185-193.

Hens, J. R., M. D. Amstutz, F. L. Schanbacher, and I. H. Mather. 2000. Introduction of the human growth hormone gene into the guinea pig mammary gland by in vivo transfection promotes sustained expression of human growth hormone in the milk throughout lactation. Biochim. Biophys. Acta 1523:161-171.

Ilan, Y., G. Droguett, N. R. Chowdhury, Y. Li, K. Sengupta, N. R. Thummala, A. Davidson, J. R. Chowdhury, and M. S. Horwitz. 1997a. Insertion of the adenoviral E3 region into a recombinant viral vector prevents antiviral humoral and cellular immune responses and permits long-term gene expression. Proc. Natl. Acad. Sci. USA 94:2587-2592.

Ilan, Y., R. Prakash, A. Davidson, V. Jona, G. Droguett, M. S. Horwitz, N. R. Chowdhury, and J. R. Chowdhury. 1997b. Oral tolerization to adenoviral antigens permits long-term gene expression using recombinant adenoviral vectors. J. Clin. Invest. 99:1098-1106.

Jeng, M. H., C. Kao, L. Sivaraman, S. Krnacik, L. W. Chung, D. Medina, O. M. Conneely, and B. W. O'Malley. 1998. Reconstitution of estrogen-dependent transcriptional activation of an adenoviral target gene in select regions of the rat mammary gland. Endocrinology 139:2916-2925.

Kerr, D. E., P. A. Furth, A. M. Powell, and R. J. Wall. 1996. Expression of gene-gun injected plasmid DNA in the ovine mammary gland and in lymph nodes draining the injection site. Anim. Biotechnol. 7:33-45.

Kerr, D. E., K. Plaut, A. J. Bramley, C. M. Williamson, A. J. Lax, K. Moore, K. D. Wells, and R. J. Wall. 2001. Lysostaphin expression in mammary glands confers protection against staphylococcal infection in transgenic mice. Nat. Biotechnol. 19:66-70.

Mittereder, N., S. Yei, C. Bachurski, J. Cuppoletti, J. A. Whitsett, P. Tolstoshev, and B. C. Trapnell. 1994. Evaluation of the efficacy and safety of in vitro, adenovirus-mediated transfer of the human cystic fibrosis transmembrane conductance regulator cDNA. Hum. Gene Ther. 5:717-729.

Oldham, E. R., and M. J. Daley. 1991. Lysostaphin: Use of a recombinant bactericidal enzyme as a mastitis therapeutic. J. Dairy. Sci. 74:4175-4182.

Patton, S., U. Welsch, and S. Singh. 1984. Intramammary infusion technique for genetic engineering of the mammary gland. J. Dairy Sci. 67:1323-1326.

Rosenfeld, M. A., K. Yoshimura, B. C. Trapnell, K. Yoneyama, E. R. Rosenthal, W. Dalemans, M. Fukayama, J. Bargon, L. E. Stier, and L. Stratford-Perricaudet. 1992. In vivo transfer of the human cystic fibrosis transmembrane conductance regulator gene to the airway epithelium. Cell 68:143-155.

Sanes, J. R., J. L. Rubenstein, and J. F. Nicolas. 1986. Use of a recombinant retrovirus to study post-implantation cell lineage in mouse embryos. EMBO J. 5:3133-3142. 
Schindler, C. A., and V. T. Schuhardt. 1964. Lysostaphin: A new bacteriolytic agent for the Staphylococcus. Proc. Natl. Acad. Sci. USA 51:414-421.

Schindler, C. A., and V. T. Schuhardt. 1965. Putification and properties of lysostaphin-a lytic agent for Spahylococcus aureus. Biochim. Biophys. Acta 97:242-250.

Smith, T. A. G., M. G. Mehaffey, D. B. Kayda, J. M. Saunders, S. Yei, B. C. Trapnell, A. McClelland, and M. Kaleko. 1993. Adenovirus mediated expression of therapeutic plasma levels of human factor IX in mice. Nat. Genet. 5:397-402.

Trapnell, B. C., and M. Gorziglia. 1994. Gene therapy using adenoviral vectors. Curr. Opin. Biotechnol. 5:617-625.
Wall, R. J., D. E. Kerr, and K. R. Bondioli. 1997. Transgenic dairy cattle: Genetic engineering on a large scale. J. Dairy Sci. 80:2213-2224.

Yang, J., T. Tsukamoto, N. Popnikolov, R. C. Guzman, X. Chen, J. H. Yang, and S. Nandi. 1995. Adenoviral-mediated gene transfer into primary human and mouse mammary epithelial cells in vitro and in vivo. Cancer Lett. 98:9-17.

Zavizion, B., M. van Duffelen, W. Schaeffer, and I. Politis. 1996. Establishment and characterization of a bovine mammary epithelial cell line with unique properties. In Vitro Cell Dev. Biol. Anim. 32:138-148. 